\title{
EFFECTIVE RENAL BLOOD FLOW IN THE SEPARATE KIDNEYS OF SUBJECTS WITH ESSENTIAL HYPERTENSION ${ }^{1}$
}

\author{
BY HERBERT CHASIS AND JULES REDISH \\ (From the Departments of Medicine and Physiology, New York University College of Medicine, and \\ the Third (New York University) Medical Division, Belleoue Hospital, New York City)
}

(Received for publication June 16, 1941)

Unilateral renal disease in man has been widely accepted as a primary cause of arterial hypertension. The assumption is made that there has been obstruction to the blood flow in the diseased kidney and that the resulting ischemic renal tissue is directly responsible for the abnormal elevation of the blood pressure. If such were the case, it seemed to us that it could be demonstrated by the examination of the separate kidneys, and this report concerns the application of the clearance methods to this problem.

\section{Application of the clearance method to unilateral studies}

The possible difficulties ${ }^{2}$ which present themselves when applying the clearance technique to unilateral measurements lie in the failure to obtain a total collection of urine by means of ureteral catheters, and the excitation of reflex renal vasoconstriction by trauma to the bladder and ureters or physical and mental discomfort associated with prolonged catheterization.

On the question of complete collection, we find that if a Number 8 French, flute-tipped, radioopaque, silk catheter with six eyes is passed only $12 \mathrm{~cm}$. up the ureter, i.e., into the portion of the ureter having the narrowest lumen, extra-catheter flow is usually avoided. The occurrence and extent of leakage around the catheter can be detected by addition of phenol red to the infusion fluid, and by inserting a third catheter in the bladder; the bladder can thus be rinsed at intervals, when leakage will be revealed by the appearance of dye in the bladder urine. Where it is possible to identify the side on which leakage

\footnotetext{
1 Aided by a grant from the Commonwealth Fund.

2 Accurate determination of the rate of urine flow might not be obtainable from a large hydronephrotic kidney, and the clearance method could be employed accurately only if the plasma concentration of diodrast and inulin were kept constant, and if no urine accumulated in the dilated pelvis.
}

occurs, analysis of bladder urine may be used to correct the data on the appropriate kidney.

With regard to reflex vasoconstriction, we believe that it occurred once in the forty-five subjects whom we have examined. In this instance it was concluded that there was vasoconstriction of the afferent glomerular arterioles, manifesting itself by a marked decrease in renal blood flow, filtration rate (constant filtration fraction) and urine volume; the spasm lasted for about twenty minutes with a gradual return to normal function at the end of one hour. Otherwise, the values observed by us in unilateral studies are comparable to those obtained in bilateral studies. Again, in ten patients who had both unilateral and bilateral tests, satisfactory agreement was found in all the values obtained by both methods.

\section{Selection of subjects}

Patients with hypertension were selected at random from the Nephritis and Hypertension Clinic of the New York University College Clinic and from the wards of the Third (New York University) Medical Division of Bellevue Hospital. There were seventeen female and four male subjects. These subjects were considered to have essential hypertension and were representative of the entire clinic population with this diagnosis. No attempt was made to choose or exclude those patients who gave evidence of urinary tract disease. It is important to note that in this random selection no instance of advanced destructive unilateral renal disease was encountered.

In addition to the twenty-one subjects here reported, hypertensive patients who had undergone splanchnicectomy, renal-omentopexy and nephropexy were also studied by the same technique and will be reported elsewhere.

Observations were also made on five normal individuals for the purpose of establishing the technique of the procedure. These normal subjects were convalescent, volunteer ward patients, in whom no evidence suggestive of renal or hypertensive disease was obtained.

\section{Procedure}

To reduce the urine flow and prevent leakage, the patients were taken off fluids for a sixteen-hour interval preceding the period of observation. They were examined 
without breakfast, the examination being made with the patient in the supine position. One-half hour before cystoscopy the majority of the patients received 0.20 gram of pentobarbital by mouth. It is believed that this sedation did not affect the measurements since repetition of the test without sedation in the same patient yielded comparable data. Following routine cystoscopic examination, Number 8 ureteral catheters were inserted about $12 \mathrm{~cm}$. up the ureters. In those instances where we failed to introduce a Number $8 \mathrm{~F}$., Number $7 \mathrm{~F}$. or Number $6 \mathrm{~F}$. catheters were used. The cystoscope was then removed, except in occasional instances when it was allowed to remain in position during the period of observation. A multi-eyed urethral catheter was then inserted into the bladder. An infusion of phenol red, diodrast and inulin was given throughout the period of observation. Following the discard period, either three urine collection periods or a single long urine collection period of about twenty-five minutes were taken and the rate of glomerular filtration and effective renal blood flow measurements were made in this time interval. In those patients in whom the measurement of the tubular excretory mass was to be made, a second series or a single urine collection period was taken after a twenty-minute discard period. For detailed data concerning the preparation of the infusion fluid, the chemical analytical methods, etc., the reader is referred to previous papers $(1,2)$.

Immediately following the clearance studies, retrograde

TABLE I

Observations on the separate kidneys of hypertensive subjects

(Columns 3, 4, 5, 6, 7, and 8 corrected to 1.73 sq. m., Column 8 corrected to $98.5^{\circ} \mathrm{F}$.)

\begin{tabular}{|c|c|c|c|c|c|c|c|c|c|c|c|}
\hline \multirow{2}{*}{ Subject } & \multirow{2}{*}{ Date } & \multicolumn{4}{|c|}{ Plasma clearances } & \multirow{2}{*}{$\begin{array}{c}\text { Effective } \\
\text { blood } \\
\text { flow }\end{array}$} & \multirow{2}{*}{$\begin{array}{c}\text { Filtra- } \\
\text { tion } \\
\text { fraction }\end{array}$} & \multirow{2}{*}{$\underset{T m}{\text { Diodrast }}$} & \multirow{2}{*}{$\frac{\begin{array}{c}\text { Diodrast } \\
\text { clearance }\end{array}}{\underset{T m}{\text { Diodrast }}}$} & \multirow{2}{*}{$\frac{\begin{array}{c}\text { Inulin } \\
\text { clearance }\end{array}}{\frac{\text { Diodrast }}{T_{m}}}$} & \multirow{2}{*}{$\begin{array}{l}\text { Plasma } \\
\text { flow } \Delta^{*}\end{array}$} \\
\hline & & & Inulin & $\begin{array}{l}\text { Phenol } \\
\text { red }\end{array}$ & Diodrast & & & & & & \\
\hline & & kidney & $\begin{array}{l}\text { cc. per } \\
\text { minute }\end{array}$ & $\begin{array}{l}\text { cc. per } \\
\text { minute }\end{array}$ & $\begin{array}{l}c c . \text { per } \\
\text { minute }\end{array}$ & $\begin{array}{l}\text { cc. per } \\
\text { minute }\end{array}$ & per cent & \multicolumn{3}{|c|}{ mgm. iodine per minute } & perce \\
\hline
\end{tabular}

HYPERTENSIVE SUBJECTS

\begin{tabular}{|c|c|c|c|c|c|c|c|c|c|c|c|c|}
\hline M. J. & May & 20,1940 & $\begin{array}{l}R \\
L\end{array}$ & $\begin{array}{l}73.3 \\
65.9\end{array}$ & $\begin{array}{l}185 \\
184\end{array}$ & $\begin{array}{l}282 \\
254\end{array}$ & $\begin{array}{l}454 \\
408\end{array}$ & $\begin{array}{l}26.0 \\
25.9\end{array}$ & $\begin{array}{l}22.6 \\
24.2\end{array}$ & $\begin{array}{l}12.4 \\
10.5\end{array}$ & $\begin{array}{l}3.24 \\
2.72\end{array}$ & $\begin{array}{l}-6.0 \\
-15.3\end{array}$ \\
\hline A. Mc. & April & 22,1940 & $\begin{array}{l}R \\
L\end{array}$ & $\begin{array}{l}46.8 \\
51.6\end{array}$ & $\begin{array}{l}122 \\
139\end{array}$ & $\begin{array}{l}154 \\
182\end{array}$ & $\begin{array}{l}249 \\
295\end{array}$ & $\begin{array}{l}30.3 \\
28.3\end{array}$ & $\begin{array}{l}20.1 \\
25.0\end{array}$ & $\begin{array}{l}7.7 \\
7.3\end{array}$ & $\begin{array}{l}2.33 \\
2.06\end{array}$ & $\begin{array}{l}-48.7 \\
-39.3\end{array}$ \\
\hline M. C. & March & 29,1940 & $\begin{array}{l}\mathrm{R} \\
\mathrm{L}\end{array}$ & $\begin{array}{l}66.1 \\
82.6\end{array}$ & $\begin{array}{l}146 \\
198\end{array}$ & $\begin{array}{l}250 \\
315\end{array}$ & $\begin{array}{l}370 \\
465\end{array}$ & $\begin{array}{l}26.5 \\
26.2\end{array}$ & $\begin{array}{l}20.9 \\
23.4\end{array}$ & $\begin{array}{l}12.0 \\
13.4\end{array}$ & $\begin{array}{l}3.16 \\
3.53\end{array}$ & $\begin{array}{l}-16.7 \\
+\quad 5.0\end{array}$ \\
\hline L. Js. & December & 19,1940 & $\begin{array}{l}\mathrm{R} \\
\mathrm{L}\end{array}$ & $\begin{array}{l}57.6 \\
56.4\end{array}$ & & $\begin{array}{l}294 \\
274\end{array}$ & $\begin{array}{l}550 \\
512\end{array}$ & $\begin{array}{l}19.6 \\
20.6\end{array}$ & $\begin{array}{l}19.4 \\
20.7\end{array}$ & $\begin{array}{l}15.2 \\
13.2\end{array}$ & $\begin{array}{l}2.97 \\
2.73\end{array}$ & $\begin{array}{l}-14.5 \\
-20.3\end{array}$ \\
\hline M. M. & April & 8,1940 & $\begin{array}{l}\mathrm{R} \\
\mathrm{L}\end{array}$ & $\begin{array}{l}61.1 \\
59.7\end{array}$ & $\begin{array}{l}150 \\
147\end{array}$ & $\begin{array}{l}194 \\
185\end{array}$ & $\begin{array}{l}377 \\
358\end{array}$ & $\begin{array}{l}31.4 \\
32.2\end{array}$ & $\begin{array}{l}18.9 \\
19.0\end{array}$ & $\begin{array}{r}10.3 \\
9.8\end{array}$ & $\begin{array}{l}3.23 \\
3.14\end{array}$ & $\begin{array}{l}-35.3 \\
-38.3\end{array}$ \\
\hline A. G. & October & 4,1940 & $\begin{array}{l}\mathbf{R} \\
\mathbf{L}\end{array}$ & $\begin{array}{l}35.7 \\
36.2\end{array}$ & & $\begin{array}{l}176 \\
180\end{array}$ & $\begin{array}{l}284 \\
295\end{array}$ & $\begin{array}{l}20.3 \\
20.1\end{array}$ & $\begin{array}{l}18.9 \\
19.7\end{array}$ & $\begin{array}{l}9.3 \\
9.1\end{array}$ & $\begin{array}{l}1.89 \\
1.84\end{array}$ & $\begin{array}{l}-41.3 \\
-46.2\end{array}$ \\
\hline A. N. & November & 4,1940 & $\begin{array}{l}\mathbf{R} \\
\mathbf{L}\end{array}$ & $\begin{array}{l}59.2 \\
60.5\end{array}$ & & $\begin{array}{l}225 \\
227\end{array}$ & $\begin{array}{l}357 \\
360\end{array}$ & $\begin{array}{l}26.3 \\
26.6\end{array}$ & $\begin{array}{l}21.8 \\
20.1\end{array}$ & $\begin{array}{l}10.3 \\
11.3\end{array}$ & $\begin{array}{l}2.71 \\
3.01\end{array}$ & $\begin{array}{l}-25.0 \\
-24.3\end{array}$ \\
\hline R. Mc. & November & 18,1940 & $\begin{array}{l}\mathbf{R} \\
\mathbf{L}\end{array}$ & $\begin{array}{l}45.1 \\
49.7\end{array}$ & & $\begin{array}{l}200 \\
216\end{array}$ & $\begin{array}{l}330 \\
357\end{array}$ & $\begin{array}{l}22.5 \\
23.0\end{array}$ & $\begin{array}{l}16.7 \\
20.2\end{array}$ & $\begin{array}{l}12.0 \\
10.7\end{array}$ & $\begin{array}{l}2.70 \\
2.41\end{array}$ & $\begin{array}{l}-33.3 \\
-28.0\end{array}$ \\
\hline F. S. & November & 14,1940 & $\begin{array}{l}\mathrm{R} \\
\mathrm{L}\end{array}$ & $\begin{array}{l}69.5 \\
72.9\end{array}$ & & $\begin{array}{l}243 \\
261\end{array}$ & $\begin{array}{l}402 \\
432\end{array}$ & $\begin{array}{l}28.7 \\
28.2\end{array}$ & $\begin{array}{l}17.4 \\
17.0\end{array}$ & $\begin{array}{l}14.0 \\
15.4\end{array}$ & $\begin{array}{l}4.00 \\
4.28\end{array}$ & $\begin{array}{l}-19.0 \\
-13.0\end{array}$ \\
\hline K. S. & May & 12,1941 & $\begin{array}{l}\mathrm{R} \\
\mathrm{L}\end{array}$ & $\begin{array}{l}59.6 \\
76.3\end{array}$ & & $\begin{array}{l}166 \\
222\end{array}$ & $\begin{array}{l}281 \\
375\end{array}$ & $\begin{array}{l}36.0 \\
34.0\end{array}$ & $\begin{array}{l}13.1 \\
20.4\end{array}$ & $\begin{array}{l}12.6 \\
10.9\end{array}$ & $\begin{array}{l}4.50 \\
3.70\end{array}$ & $\begin{array}{l}-50.4 \\
-33.7\end{array}$ \\
\hline L. S. & April & 15,1940 & $\begin{array}{l}\mathrm{R} \\
\mathrm{L}\end{array}$ & $\begin{array}{l}49.4 \\
52.2\end{array}$ & $\begin{array}{l}121 \\
124\end{array}$ & $\begin{array}{l}211 \\
213\end{array}$ & $\begin{array}{l}398 \\
401\end{array}$ & $\begin{array}{l}23.5 \\
24.5\end{array}$ & $\begin{array}{l}15.4 \\
17.4\end{array}$ & $\begin{array}{l}13.7 \\
12.2\end{array}$ & $\begin{array}{l}3.20 \\
3.00\end{array}$ & $\begin{array}{l}-29.7 \\
-29.0\end{array}$ \\
\hline A. $\mathbf{M g}$. & September & 27,1940 & $\begin{array}{l}\mathrm{R} \\
\mathrm{L}\end{array}$ & $\begin{array}{l}56.3 \dagger \\
\mathbf{5 6 . 0 \dagger}\end{array}$ & & $\begin{array}{l}220 \\
199\end{array}$ & $\begin{array}{l}392 \\
354\end{array}$ & $\begin{array}{l}25.6 \\
28.1\end{array}$ & $\begin{array}{l}14.8 \\
17.8\end{array}$ & $\begin{array}{l}14.9 \\
11.2\end{array}$ & $\begin{array}{l}3.80 \\
3.10\end{array}$ & $\begin{array}{l}-26.6 \\
-33.3\end{array}$ \\
\hline F. K. & May & 27,1940 & $\begin{array}{l}\mathbf{R} \\
\mathbf{L}\end{array}$ & $\begin{array}{l}63.0 \\
68.0\end{array}$ & $\begin{array}{l}158 \\
171\end{array}$ & $\begin{array}{l}303 \\
330\end{array}$ & $\begin{array}{l}564 \\
615\end{array}$ & $\begin{array}{l}20.8 \\
20.6\end{array}$ & $\begin{array}{l}16.2 \\
15.2\end{array}$ & $\begin{array}{l}18.7 \\
21.7\end{array}$ & $\begin{array}{l}3.88 \\
4.47\end{array}$ & $\begin{array}{r}-11.9 \\
-4.1\end{array}$ \\
\hline
\end{tabular}


RENAL BLOOD FLOW IN HYPERTENSION

TABLE I-Continued

\begin{tabular}{|c|c|c|c|c|c|c|c|c|c|c|c|c|}
\hline \multirow{3}{*}{ Subject } & \multirow{2}{*}{\multicolumn{2}{|c|}{ Date }} & \multicolumn{4}{|c|}{ Plasma clearances } & \multirow{2}{*}{$\begin{array}{l}\text { Effective } \\
\text { blood } \\
\text { flow }\end{array}$} & \multirow{2}{*}{$\begin{array}{c}\text { Filtra- } \\
\text { tion } \\
\text { fraction }\end{array}$} & \multirow{2}{*}{$\begin{array}{c}\text { Diodrast } \\
T m\end{array}$} & \multirow{2}{*}{$\mid \begin{array}{c}\text { Diodrast } \\
\text { clearance } \\
\begin{array}{c}\text { Diodrast } \\
T m\end{array}\end{array}$} & \multirow{2}{*}{$\frac{\begin{array}{c}\text { Inulin } \\
\text { clearance }\end{array}}{\begin{array}{c}\text { Diodrast } \\
\text { Tm }\end{array}}$} & \multirow{2}{*}{$\begin{array}{l}\text { Plasma } \\
\text { flow } \Delta^{*}\end{array}$} \\
\hline & & & \multirow[b]{2}{*}{ kidney } & \multirow{2}{*}{$\frac{\text { Inulin }}{\underbrace{\text { minute }}_{\text {cc. per }}}$} & \multirow{2}{*}{$\frac{\begin{array}{c}\text { Phenol } \\
\text { red }\end{array}}{\underbrace{c c \text { per }}_{\text {minute }}}$} & \multirow{2}{*}{\begin{tabular}{|l|} 
Diodrast \\
$\begin{array}{l}\text { ce. per } \\
\text { minute }\end{array}$ \\
\end{tabular}} & & & & & & \\
\hline & & & & & & & $\begin{array}{l}c c \text { per } \\
\text { minute }\end{array}$ & per cent & \multicolumn{3}{|c|}{ mgm. iodine per minute } & per cent \\
\hline \multicolumn{13}{|c|}{ HYPERTENSIVE SUBJECTS-Continued } \\
\hline E. D. & June & 24,1940 & $\begin{array}{l}R \\
L\end{array}$ & $\begin{array}{l}53.8 \\
48.4\end{array}$ & & $\begin{array}{l}220 \\
205\end{array}$ & $\begin{array}{l}331 \\
308\end{array}$ & $\begin{array}{l}24.3 \\
23.3\end{array}$ & $\begin{array}{l}15.8 \\
14.8\end{array}$ & $\begin{array}{l}13.9 \\
13.8\end{array}$ & $\begin{array}{l}3.39 \\
3.27\end{array}$ & $\begin{array}{l}-26.7 \\
-31.6\end{array}$ \\
\hline E. Wa. & April & 1,1940 & $\begin{array}{l}R \\
L\end{array}$ & $\begin{array}{l}40.2 \\
40.8\end{array}$ & & $\begin{array}{l}162 \\
146\end{array}$ & $\begin{array}{l}270 \\
243\end{array}$ & $\begin{array}{l}24.9 \\
27.9\end{array}$ & $\begin{array}{l}14.9 \\
14.7\end{array}$ & $\begin{array}{r}10.8 \\
9.9\end{array}$ & $\begin{array}{l}2.69 \\
2.77\end{array}$ & $\begin{array}{l}-52.9 \\
-57.8\end{array}$ \\
\hline G. F. & November & 25,1940 & $\begin{array}{l}\mathbf{R} \\
\mathbf{L}\end{array}$ & $\begin{array}{l}45.9 \\
40.2\end{array}$ & & $\begin{array}{l}225 \\
208\end{array}$ & $\begin{array}{l}384 \\
355\end{array}$ & $\begin{array}{l}20.4 \\
19.3\end{array}$ & & & & $\begin{array}{l}-25.0 \\
-30.8\end{array}$ \\
\hline C. B. & December & 29,1939 & $\begin{array}{l}R \\
L\end{array}$ & $\begin{array}{l}52.9 \\
50.2\end{array}$ & $\begin{array}{l}135 \\
123\end{array}$ & . & $\begin{array}{l}381 \ddagger \\
348 \ddagger\end{array}$ & $\begin{array}{l}23.5 \\
24.5\end{array}$ & & & & $\begin{array}{l}-25.0 \\
-31.6\end{array}$ \\
\hline R. B. & January & 22,1940 & $\begin{array}{l}\mathbf{R} \\
\mathrm{L}\end{array}$ & $\begin{array}{l}51.4 \\
51.9\end{array}$ & $\begin{array}{l}123 \\
123\end{array}$ & & $\begin{array}{l}348 \ddagger \\
348 \ddagger\end{array}$ & $\begin{array}{l}25.0 \\
25.3\end{array}$ & & & & $\begin{array}{l}-31.6 \\
-31.6\end{array}$ \\
\hline S. R. & May & 10,1940 & $\begin{array}{l}\mathbf{R} \\
\mathbf{L}\end{array}$ & $\begin{array}{l}58.2 \\
55.6\end{array}$ & & $\begin{array}{l}187 \\
173\end{array}$ & $\begin{array}{l}328 \\
304\end{array}$ & $\begin{array}{l}32.1 \\
31.1\end{array}$ & & & & $\begin{array}{l}-37.6 \\
-42.3\end{array}$ \\
\hline J. C. & January & 15,1940 & $\begin{array}{l}\mathrm{R} \\
\mathrm{L}\end{array}$ & $\begin{array}{l}45.6 \\
40.4\end{array}$ & $\begin{array}{l}114 \\
104\end{array}$ & & $\begin{array}{l}322 \ddagger \\
294 \ddagger\end{array}$ & $\begin{array}{l}24.0 \\
23.3\end{array}$ & & & & $\begin{array}{l}-36.7 \\
-42.3\end{array}$ \\
\hline S. K. & October & 7,1940 & $\begin{array}{l}\mathbf{R} \\
\mathbf{L}\end{array}$ & $\begin{array}{l}46.3 \\
53.3\end{array}$ & & $\begin{array}{l}164 \\
194\end{array}$ & $\begin{array}{l}280 \\
332\end{array}$ & $\begin{array}{l}28.4 \\
27.5\end{array}$ & & & & $\begin{array}{l}-52.3 \\
-43.6\end{array}$ \\
\hline & & & & & NORMAI & SUBJECT & & & & & & \\
\hline E. $\mathrm{H}$. & November & 20,1939 & $\begin{array}{l}\mathrm{R} \\
\mathrm{L}\end{array}$ & & $\begin{array}{l}205 \\
221\end{array}$ & & $\begin{array}{l}6108 \\
6588\end{array}$ & & & & & $\begin{array}{r}+7.5 \\
+15.8\end{array}$ \\
\hline S. P. & February & 26,1940 & $\begin{array}{l}R \\
L\end{array}$ & $\begin{array}{l}60 \\
70\end{array}$ & $\begin{array}{l}162 \\
194\end{array}$ & & $\begin{array}{l}5098 \\
6108\end{array}$ & $\begin{array}{l}21.0 \\
20.5\end{array}$ & & & & $\begin{array}{r}-14.9 \\
+\quad 1.8\end{array}$ \\
\hline D. P. & March & 4,1940 & $\begin{array}{l}R \\
L\end{array}$ & $\begin{array}{l}57.6 \\
64.9\end{array}$ & $\begin{array}{l}173 \\
189\end{array}$ & & $\begin{array}{l}5038 \\
5548\end{array}$ & $\begin{array}{l}18.9 \\
19.5\end{array}$ & & & & $\begin{array}{l}-9.2 \\
-\quad 0.9\end{array}$ \\
\hline C. J. & March & 20,1940 & $\begin{array}{l}\mathrm{R} \\
\mathrm{L}\end{array}$ & $\begin{array}{l}55.2 \\
51.8\end{array}$ & $\begin{array}{l}183 \\
178\end{array}$ & $\begin{array}{l}297 \\
281\end{array}$ & $\begin{array}{l}457 \\
433\end{array}$ & $\begin{array}{l}18.6 \\
18.4\end{array}$ & & & & $\begin{array}{l}-11.3 \\
-16.1\end{array}$ \\
\hline W. J. & March & 25,1940 & $\begin{array}{l}\mathbf{R} \\
\mathbf{L}\end{array}$ & $\begin{array}{l}75 \\
67.8\end{array}$ & $\begin{array}{l}237 \\
234\end{array}$ & $\begin{array}{l}366 \\
360\end{array}$ & $\begin{array}{l}631 \\
621\end{array}$ & $\begin{array}{l}20.5 \\
18.8\end{array}$ & $\begin{array}{l}31 \\
30.3\end{array}$ & $\begin{array}{l}11.8 \\
11.9\end{array}$ & $\begin{array}{l}2.42 \\
2.24\end{array}$ & $\begin{array}{r}+9.5 \\
+7.6\end{array}$ \\
\hline
\end{tabular}

* Variation from one-half the mean value for effective plasma flow in normal men and women.

$\dagger$ Uncertain plasma inulin. $\quad \ddagger C_{P R} / C_{D}$ assumed as 0.60 . $\$ C_{P R} / C_{D}$ assumed as 0.57

pyelograms were made, the results of which will be reported at another time. Blood pressure and body temperature were also determined at the time of examination.

In ten instances out of forty-five a reaction followed catheterization, consisting of fever, costovertebral pain, hematuria and dysuria. These symptoms persisted for about twenty-four hours.

\section{Filtration rate, effective blood flow and tubular excretory mass}

The data obtained on five normal subjects studied with the unilateral clearance technique are given in Table I. The combined right and left renal blood flow, filtration rate and diodrast $T m\left(T m_{D}\right)$ measurements obtained in this group agree satisfactorily with those obtained in thirtyfive normal subjects observed using the bilateral technique (2). Function is fairly equally divided between the two kidneys.

The data obtained on twenty-one patients with hypertension are given in Table I. $T m_{D}$ was measured in only fifteen subjects, and the data on the remaining six patients have not been 


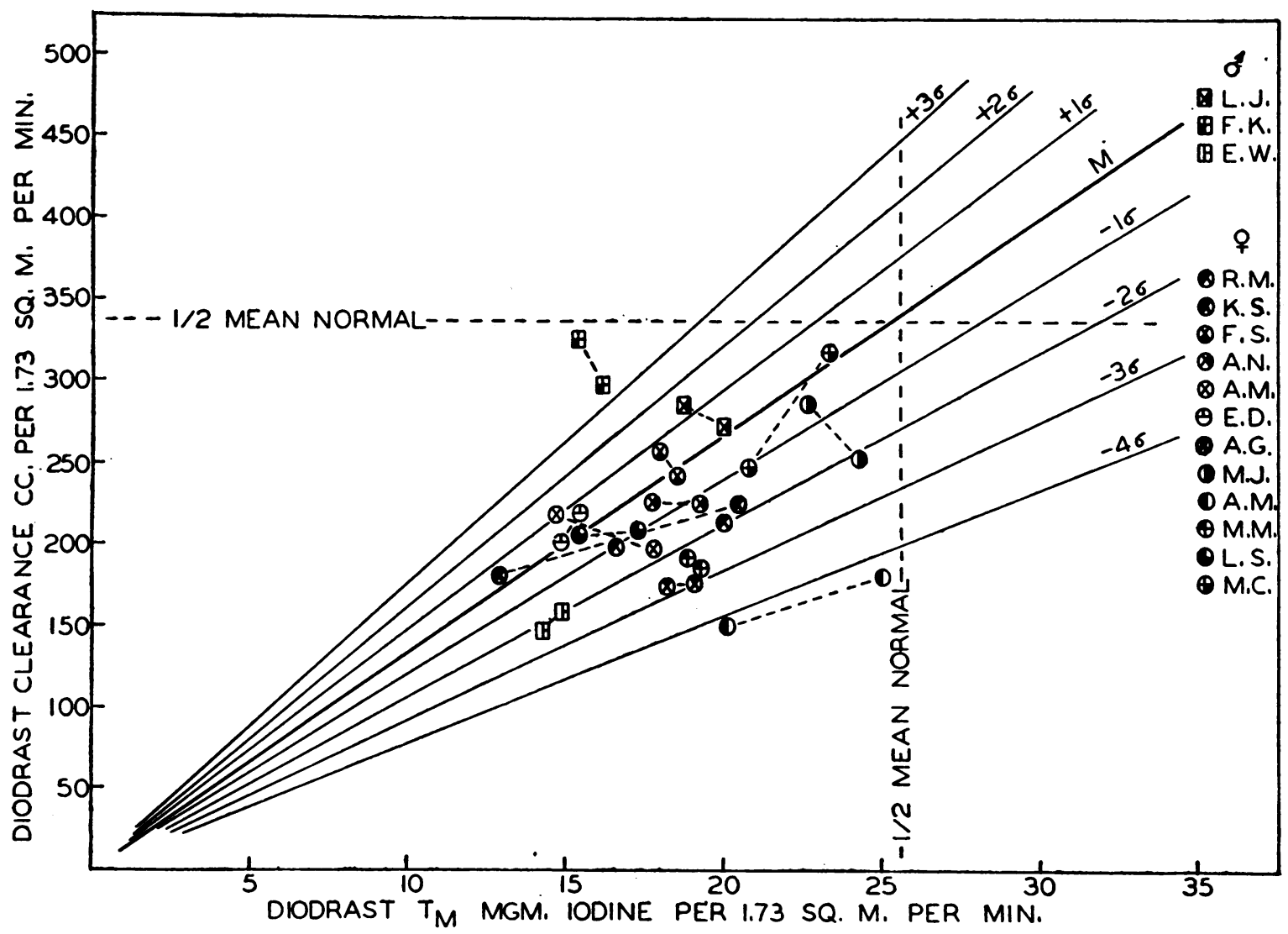

Fig. 1. Diodrast Clearance (Effective Renal Plasma Flow) in the Separate Kidneys of Hypertensive Subjects, Related to Diodrast $T m$ (Tubular Excretory Mass)

Statistical background as in Figure 1 of preceding paper (3).

included in Figures 1, 2 and 3 because of the lack of $T m_{D}$ measurement.

The combined right and left filtration rate, renal blood flow and tubular excretory mass in the fifteen hypertensive subjects have been included in a previous paper (3) and, so far as general renal function is concerned, need not be discussed here.

In Figure 1 the diodrast clearance $\left(C_{D}\right)$ in fifteen hypertensive patients (each point representing the datum obtained in one kidney) is plotted against diodrast $T m\left(T m_{D}\right)$. The values for either kidney are joined by a broken line. It will be noted that in every instance in the thirty kidneys of the fifteen hypertensive subjects, both $C_{D}$ and $T m_{D}$ are less than one-half the mean normal value (2). In no instance, it will be noted, is there a significant difference in $C_{D}$ in the separate kidneys of the same subject.
The reduction in $T m_{D}$ which characterizes hypertensive disease has been interpreted as indicating impairment of tubular function (3).

Using the more significant ratio, $C_{D} / T m_{D}$, twenty-one of the thirty kidneys lie on or below the expected mean normal value, indicated by the heavy line $M$. This would suggest that, in the majority of instances, the individual kidneys of these subjects are relatively ischemic. More important, however, is our failure to observe a single instance in which $C_{D} / T m_{D}$ varied significantly in the separate kidneys of the same individual. In other words, unilateral renal ischemia is not present.

In Figure 2 the inulin clearance $\left(C_{I N}\right)$ is plotted against $T m_{D}$. The heavy line designated $M$ represents the mean normal value of $C_{I N} / T m_{D}$ in normal males and females. Each point again represents the values for a single kidney. It will 
be noted that in twenty of the thirty kidneys the inulin clearance is on or below the mean value observed in normal males and females. The primary cause for this reduction in filtration rate is believed to be obliteration of glomeruli in both kidneys.

If we relate the rate of glomerular filtration to diodrast $T m\left(C_{I N} / T m_{D}\right)$, as in Table I, twentyfive out of the thirty observations on the individual kidneys exceed the expected mean normal value, $M$. This is interpreted as indicating that the filtration rate per unit of tubular excretory mass is high in these hypertensive subjects, despite the fact that the absolute rate of filtration has been decreased. In accordance with the interpretation accorded this anomalous relationship in the preceding paper (3), i.e., that the high filtration rate is associated with a vicarious hyperemia of the residual functional tissue, we may delete the anomalous subjects from Figure 1 ; then in every instance $C_{D} / T m_{D}$ is invariably below the normal value in both kidneys. We conclude from this fact that the ischemic tendency is equally operative in the two kidneys of those subjects who reveal it in respect to total renal function.

Figure 3 shows that the filtration fraction of the separate kidneys tends to be equally elevated in the characteristic hypertensive manner. (For a description of the normal statistical background see our previous paper (3).) If those patients who show evidence of vicarious hyperemia (as indicated by high $C_{I N} / T m_{D}$ ) are deleted from Figure 3, the remaining observations fall within the normal parameters, indicating efferent arteriolar constriction in these kidneys.

In brief, these observations show that the two kidneys in these subjects are equally affected

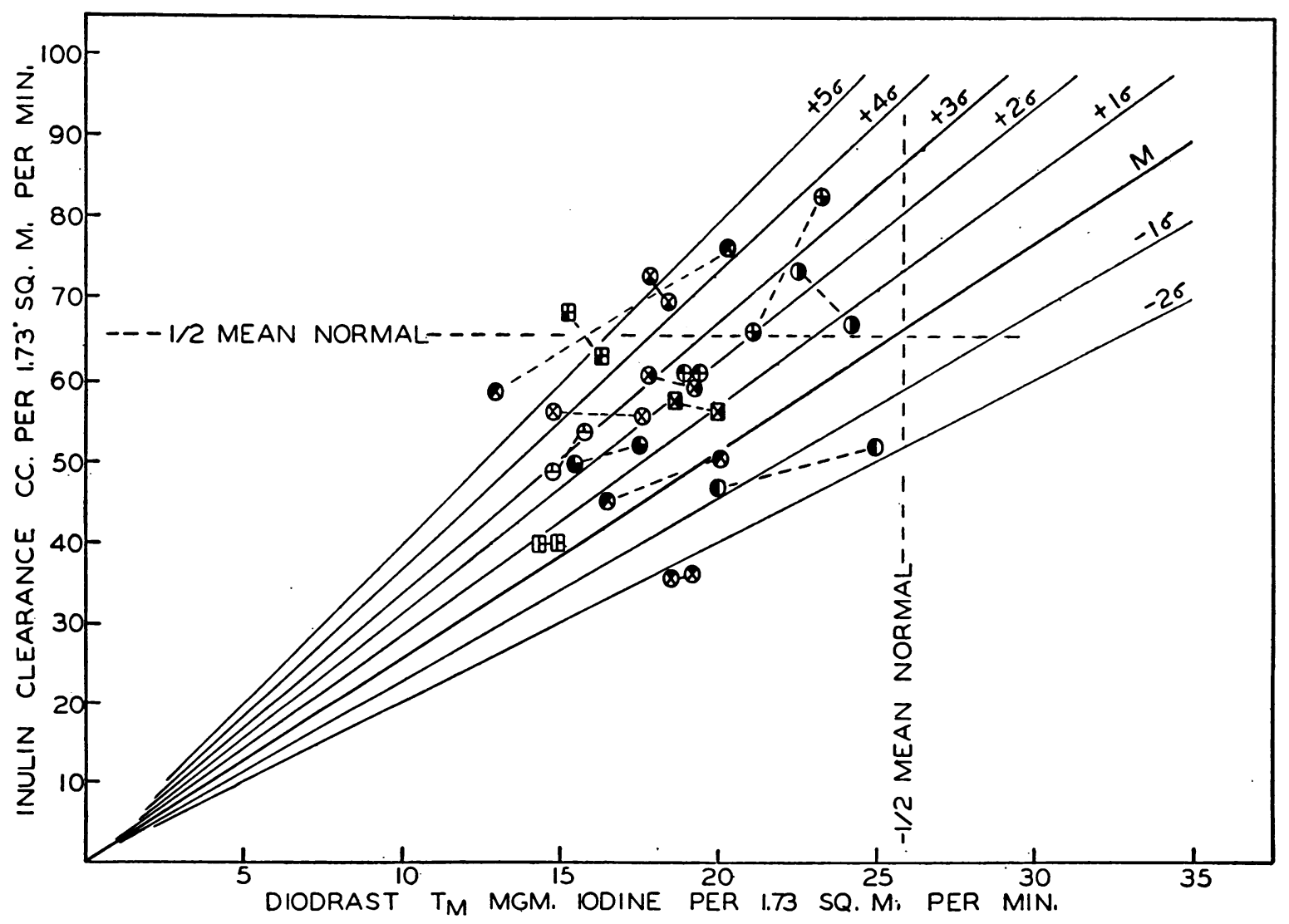

Fig. 2. Inulin Clearance (Filtration Rate) in the Separate Kidneys of Hypertensive Subjects, RELated to Diodrast $T m$

Statistical background as in Figure 2 of preceding paper (3). 


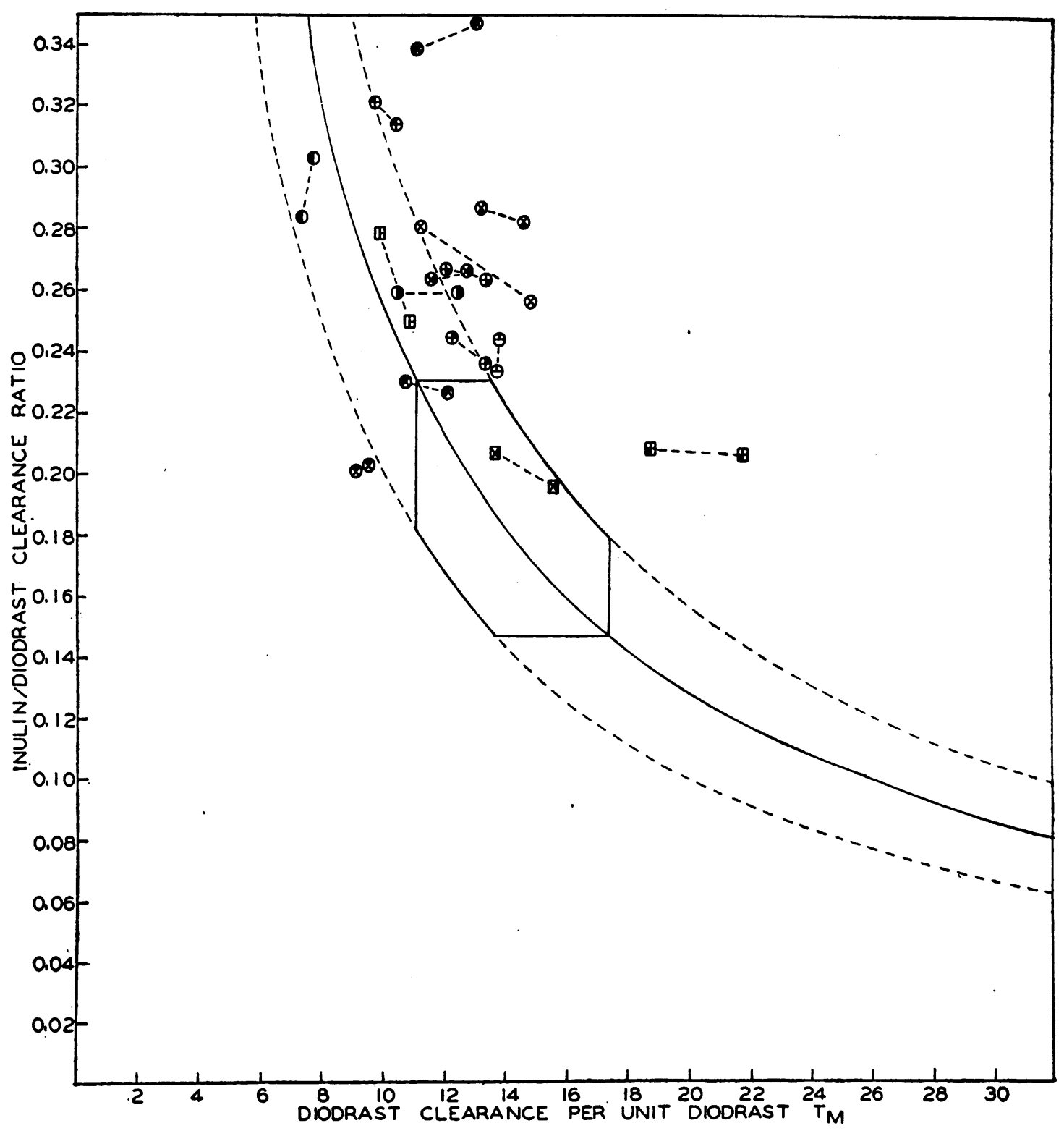

Fig. 3. Inulin/Diodrast Clearance Ratio (Filtration Fraction) in the Separate Kidneys of Hypertensive Subjects, Related to Effective Renal Plasma flow Per Unit of Tubular Excretory Mass

Statistical background as in Figure 5 of preceding paper (3).

with respect to $C_{D}, T m_{D}$ and $C_{I N} / T m_{D}$. In the six hypertensive subjects in whom only $C_{I N}$ and $C_{D}$ were measured, the two kidneys shared equally in a marked decrease in $C_{D}$ and a more moderate decrease in $C_{I N}, C_{I N} / C_{D}$ being invariably above the mean normal value. Although one cannot interpret the data in these six subjects with the same confidence as in the group in which $T m_{D}$ was measured, the fact that $C_{D}$ and $C_{I N}$ were reduced equally in the two kidneys indicates that in these subjects also unilateral renal ischemia is not present.

\section{CONCLUSION}

The clearance method has been applied to the measurement of the renal blood flow, the filtra- 
tion rate and the tubular excretory mass in the separate kidneys of patients with essential hypertension. The results of these observations indicate that the destruction of tubular tissue progresses equally on the two sides in hypertensive disease and that the functional disturbance in respect to blood flow and filtration rate is shared equally by the two kidneys.

In no instance in the twenty-one hypertensive subjects picked at random is there any indication of a unilateral ischemic kidney. If it is predicated that renal ischemia is the primary causal factor in all essential hypertension, it would be expected that unilateral impairment of renal function would be observed more frequently than bilateral impairment. The absence of unilateral impairment in these subjects argues against the above premise.

\section{BIBLIOGRAPHY}

1. Smith, H. W., Goldring, W., and Chasis, H., The measurement of the tubular excretory mass, effective renal blood flow and filtration rate in the normal human kidney. J. Clin. Invest., 1938, 17, 263.

2. Goldring, W., Chasis, H., Ranges, H. A., and Smith, H. W., Relations of effective renal blood flow and glomerular filtration to tubular excretory mass in normal man. J. Clin. Invest., 1940, 19, 739.

3. Goldring, W., Chasis, H., Ranges, H. A., and Smith, H. W., Effective renal .blood flow in subjects with essential hypertension. J. Clin. Invest., 1941, 20, 637. 